\title{
GCU
}

Glasgow Caledonian

University

University for the Common Good

\section{Rape myth acceptance, victim blame attribution and Just World Beliefs: a rapid evidence assessment}

Russell, Kirsten J.; Hand, Christopher J.

Published in:

Aggression and Violent Behavior

DOI:

10.1016/j.avb.2017.10.008

Publication date:

2017

Document Version

Author accepted manuscript

Link to publication in ResearchOnline

Citation for published version (Harvard):

Russell, KJ \& Hand, CJ 2017, 'Rape myth acceptance, victim blame attribution and Just World Beliefs: a rapid evidence assessment', Aggression and Violent Behavior, vol. 37, pp. 153-160.

https://doi.org/10.1016/j.avb.2017.10.008

\section{General rights}

Copyright and moral rights for the publications made accessible in the public portal are retained by the authors and/or other copyright owners and it is a condition of accessing publications that users recognise and abide by the legal requirements associated with these rights.

Take down policy

If you believe that this document breaches copyright please view our takedown policy at https://edshare.gcu.ac.uk/id/eprint/5179 for details of how to contact us. 
RAPE MYTHS, VICTIM BLAME AND JUST-WORLD BELIEFS

Rape Myth Acceptance, Victim Blame Attribution and Just World Beliefs:

\section{A Rapid Evidence Assessment}

Kirsten J. Russell ${ }^{\mathrm{a}}$ \& Christopher J. Hand ${ }^{\mathrm{a}^{*}}$

${ }^{a}$ School of Health and Life Sciences, Glasgow Caledonian University, Cowcaddens Road, Glasgow, G4 0BA, United Kingdom

Kirsten J. Russell, School of Health and Life Sciences,

Glasgow Caledonian University, Cowcaddens Road, Glasgow, G4 0BA, United Kingdom krusse200@,caledonian.ac.uk

Christopher J. Hand, School of Health and Life Sciences,

Glasgow Caledonian University, Cowcaddens Road, Glasgow, G4 0BA, United Kingdom christopher.hand@gcu.ac.uk

*Corresponding Author:

Dr. Christopher J. Hand

School of Health and Life Sciences

Glasgow Caledonian University

Cowcaddens Road

Glasgow

G4 0BA

United Kingdom

Telephone: $\quad+44(0) 1412731548$

Email: $\quad$ christopher.hand@gcu.ac.uk

\section{Funding Acknowledgement}

This research did not receive any specific funding from agencies in the public, commercial, or not-for-profit sectors. 


\begin{abstract}
Background

Rape is underreported, potentially because individuals self-blame and/or are blamed by others. Research predominantly illustrates male-perpetrated stranger-rape of females; thus, there may be a perception that rape-myth acceptance (RMA) and victim-blaming are most prevalent in males. The purpose of this rapid evidence assessment was to investigate the availability of high-quality research into the effects of Just World Beliefs, perpetrator/victim gender, and stranger- and acquaintance/marital-rape scenarios on victim-blaming and RMA.

\section{Methods}

Several electronic databases were searched for empirical papers using terms including: 'victim blame', 'rape myth acceptance', 'Just World Beliefs', 'type of rape' and 'gender'. Gough's (2007) weight of evidence framework was used to assess quality prior to inclusion.

\title{
Findings
}

Studies retained after filtering and quality assessment suggested that RMA was predictive of victim-blaming with both male and female 'victims'. Rape-myth acceptance is more prevalent in males even in male 'victim' scenarios, and Just World Belief was positively associated with RMA. Greater victim-blaming was attributed in stranger- vs. acquaintancerape scenarios.

\section{Discussion}

There are no absolute conclusions regarding the role of gender or situational factors and rapesupportive/victim-blaming attitudes. Further empirical research is required to understand the prevalence of RMA in perceptions of marital rape and, particularly, homosexual marital rape.

Keywords rape myth acceptance; victim blame; just world belief; victim gender; perpetrator gender; type of rape. 
RAPE MYTHS, VICTIM BLAME AND JUST-WORLD BELIEFS

\subsection{Introduction}

Obtaining accurate statistics regarding sexual offences is problematic as many such crimes are not reported to the police (Grubb \& Harrower, 2009). A report in 2015 stated that sexual offences had increased 29\% since 2014 (Office for National Statistics, 2016). There has since been a $12 \%$ increase of recorded sexual offences in the UK $(116,012$ including attempted offences) since the end of 2015 (Flately, 2017). Despite these statistics demonstrating an upward trend in the number of complainants, this increase may be as a result of an improvement in recording sexual offences and willingness to report an offence (Flately, 2017). The survey showed the proportion of adults (aged 16-59) who have reported sexual offences has not significantly changed since the last report ( $2 \%$ compared to $1.7 \%$ last year). Some researchers suggest that recent high-profile and historic reporting of sexual offences may have influenced this increase (Office for National Statistics, 2016). According to Flately (2016), only one in 30 rape victims sees the perpetrator brought to justice - a possible reason victims do not want to report the offence to the police. Only an estimated $15 \%$ of rape victims report the crime to the police (Ministry of Justice, 2013). However, this data should be interpreted cautiously, given that true number of individuals who do not report a sexual offence to the police may be unquantifiable.

\footnotetext{
${ }^{1} \mathrm{VB}=$ victim-blaming;

${ }^{2} \mathrm{RSA}=$ rape-supportive attitude;

${ }^{3} \mathrm{RMA}=$ rape-myth acceptance;

${ }^{4} \mathrm{JWB}=$ Just World Belief;

${ }^{5} \mathrm{WoE}=$ weight of evidence (Gough, 2007);

${ }^{6}$ ARVS = Attitudes towards Rape Victims Scale (Ward, 1988);

${ }^{7} \mathrm{VBA}=$ Victim Blaming Attributions;

${ }^{8} \mathrm{MRMS}=$ Male Rape Myth Scale;

${ }^{9}$ SRES = Sex-Role Egalitarianism Scale;

${ }^{10}$ Illinois Rape Myth Acceptance scale (Payne, Lonsway \& Fitzgerald, 1999)
} 
RAPE MYTHS, VICTIM BLAME AND JUST-WORLD BELIEFS

A wealth of research evidence suggests that among the most common reasons why individuals do not report a sexual offence are self-blaming attitudes and the belief that others would blame them. Grubb and Turner (2012) report that complainants may fear that they will be ignored by the authorities, that the crime is not important enough to report or that they are embarrassed about the attack. Victim-blaming $\left(\mathrm{VB}^{1}\right)$ attributions can be used negatively by others or by complainants themselves (Mahoney \& Williams, 1998). Literature suggests that the acceptance of such VB beliefs predicts the likelihood of demonstrating rape-supportive attitudes (RSAs ${ }^{2}$; Frese, Moya \& Megias, 2004). Duff and Tostevin (2015) suggest that to fully understand how VB attributions and rape-myth acceptance $\left(\mathrm{RMA}^{3}\right)$ develop, it is important to investigate typical attitudes towards rape within the general population.

Whatley (2005) explains that for individuals to understand rape and sexual offences, many try to somehow justify the act, for example: that the complainant consumed alcohol before the offence occurred, that the complainant did not fight back, or that the complainant was being seductive (Duff \& Tostevin, 2015; Lodewijkx, Wildschut, Nijstad, Savenije, \& Smit, 2001). Dalbert (2009) illustrates that the desire to believe in a Just World (Lerner \& Simmons, 1966) influences individuals' social perceptions and, unfortunately, can result in blaming complainants for the sexual offence and accepting that the offence happened for reasons favouring the perpetrator. Previous evidence has illustrated that Just World Beliefs $\left(\mathrm{JWBs}^{4}\right)$ may predict RSAs and can illustrate how VB transpires. Strömwall, Alfredsson and Landström (2012) found that respondents with stronger JWBs attributed more victim-blame and less perpetrator-blame and female respondents with strong JWBs blamed complainants in a stranger-rape scenario. Furthermore, Hayes, Lorenz and Bell (2013) found that weaker JWBs were associated with lower VB attributions. Yet, other researchers have found no relationship between JWBs and VB attributions (e.g., Sleath \& Woodhams, 2014). Previous literature, therefore, is inconclusive regarding RMA, VB and JWBs. 
RAPE MYTHS, VICTIM BLAME AND JUST-WORLD BELIEFS

It has been widely reported that RMA is more prevalent among males than females (Grubb \& Harrower, 2009). However, it is clear that most studies have been conducted with portrayals of females as complainants and males as alleged perpetrators (e.g., Davies, Pollard \& Archer, 2006; Gurnham, 2016). Research has most commonly focussed on rape between heterosexual pairs, as predominantly the most common type of rape is male-perpetrated rape of a female. Yet, there is a lack of research regarding rape perpetrated by females, and an even less researched area where perpetrators and complainants are of the same sex (homosexual rape; Ayala, Kotary \& Hetz, 2015; Rye, Greartrix \& Enright, 2006; Sleath \& Bull, 2010). Furthermore, regardless of the gender of perpetrators/complainants, type of rape is also an important variable in terms of laypersons' attitudes. Strömwall et al. (2012) suggest that the closer the relationship between complainant and perpetrator, the more likely the complainant is to be blamed for the assault. Recently, stranger- and acquaintance-rape have been compared, however the results reported by such studies are inconsistent (Davies, Walker, Archer \& Pollard, 2010; Ferro, Cermele \& Saltzman, 2008; Frese et al., 2004). Although stranger-rape has most recently been compared to date-rape and acquaintance-rape (Grubb \& Harrower, 2009; Osman, 2014) there is a lack of research literature regarding marital or spousal rape, specifically homosexual marital rape. In the UK, gay marriage was only legalised in December 2014, therefore prior to this, homosexual marital rape could not have been studied in a valid socio-legal context, and as yet, has not been directly compared to heterosexual marital rape. Given inconsistent findings from previous literature further investigation into the effect of complainant- and perpetratorgender, and a comparison of homosexual and heterosexual rape is also required.

In the early $21^{\text {st }}$ century, the definition of rape was enhanced and broadened in the United Kingdom following both the Sexual Offences Act (2003) and the Sexual Offences (Scotland) Act (2009). Many changes have occurred; for example, consent is now regarded as 
RAPE MYTHS, VICTIM BLAME AND JUST-WORLD BELIEFS

statute, therefore children, young people and vulnerable people are better protected by this definition. Moreover, both male and female complainants are now included in the definition, and these Acts have also introduced penetration or forceful entry to mouth and anus without any reasonable belief that the other party did not consent as rape. As such, many studies conducted prior to such changes could have excluded or missed sexual acts which may be of current socio-legal importance.

The overall aim of this rapid evidence assessment was to provide a systematic-style review of studies into public attitudes towards rape, regarding different types of rape, victim/complainant gender and perpetrator gender. Investigating the general population's understanding and attitudes towards such rape situations is important, as these are the individuals who could potentially act as part of a jury in a criminal trial. Furthermore, understanding the prevalence and severity of RSAs, RMA and VB across a variety of contexts (perpetrator/victim gender, rape type) will inform the need for education and awareness campaigns.

The current rapid evidence assessment focussed on studies of RMA, JWBs, and sought to identify studies which manipulated the type of rape, victim/complainant gender and perpetrator gender. After an initial search of research literature, inclusion/exclusion criteria were applied, including an assessment of 'quality' (Gough, 2007; see 2.1 Method below and Appendix A). This rapid evidence assessment was conducted to establish whether laypersons perceive victims/complainants as more or less to blame due to gender, with consideration for the type of rape. 
RAPE MYTHS, VICTIM BLAME AND JUST-WORLD BELIEFS

\subsection{Method}

\subsubsection{Rapid Evidence Assessment}

We present a Rapid Evidence Assessment, a briefer version of a systematic review. A rapid evidence assessment is accepted as a respectable alternative; both approaches are thorough and compare quality criteria, whilst a rapid evidence assessment is more resourceefficient (Berry, Briggs, Erol \& van Staden, 2011). Within a rapid evidence assessment, the question investigated is narrower than that of a systematic review and the number of databases used is typically smaller (Berry et al., 2011). The rapid evidence assessment includes a focused search of keywords to acquire specific articles, extracting data from these articles and critically appraising them in regards to the present research question. The first stage was to search and identify literature using the search terms explained in the Search Strategy (see Section 2.1.4). The rapid evidence assessment allowed us to identify and critically evaluate articles which addressed similar questions to that of our own research question, to include sources of only the highest quality and allowed us to recognise gaps in the literature in this area (Davies, 2003). Inclusion and exclusion criteria were developed once the first general literature search had been undertaken. Only academic electronic databases were used.

Many other similar methods exist to rapid evidence assessments; however these do not boast the advantages of a rapid evidence assessment. The process of the rapid evidence assessment can be replicated - advantageous for future investigations or updating the present rapid evidence assessment. The searches undertaken reduce any potential bias which may be present and allowed us to declare definite and valuable conclusions. 
RAPE MYTHS, VICTIM BLAME AND JUST-WORLD BELIEFS

\subsubsection{Research Question}

To acquire the best quality and most relevant articles a research question was developed to direct the rapid evidence assessment and processes involved. The research question was:

- Are laypersons' rape-myth attitudes, Just World Beliefs and victim-blaming attributions influenced by the type of rape, victim and/or perpetrator gender?

\subsubsection{Inclusion and Exclusion Criteria}

The literature search primarily focussed on studies originally published in English. We aimed to identify empirical articles concerning RMA, VB attributions and JWBs. Furthermore, other variables such as type of rape (stranger, marital) and perpetrator gender were also searched for. For inclusion in the first general search, articles regarding RMA had to investigate the participant's attitudes of the RMA and VB explicitly and had to be of an empirical nature. Articles searched had to be peer-reviewed, and published between 2009 and 2016 to reflect contemporary societal attitudes. Articles were excluded if they primarily focused on race, support for rape survivors or prevention of rape, and if participants were a small, ungeneralisable population (e.g., Thai students living in the United States).

\subsubsection{Search Strategy}

The first search was a general search for the concept of RMA, VB and JWBs, searching for these specific terms independently. Electronic databases searched were ProQuest Central (including PsycInfo), Cumulative Index to Nursing and Allied Health Literature, [HOST INSTITUTION] Library search and Google Scholar. Moreover, key terms were also searched on the following websites for definitions and statistics: The UK Government (https://www.gov.uk/), UK Government Statistics (https://www.gov.uk/government/statistics), and Scottish Government statistics (http://www.gov.scot/Publications/Recent). No search of 'grey literature' was conducted, 
RAPE MYTHS, VICTIM BLAME AND JUST-WORLD BELIEFS

therefore only published articles were included. A PRISMA Flow Diagram can be found in Figure 1 illustrating the specific filters and number of articles found. 
RAPE MYTHS, VICTIM BLAME AND JUST-WORLD BELIEFS

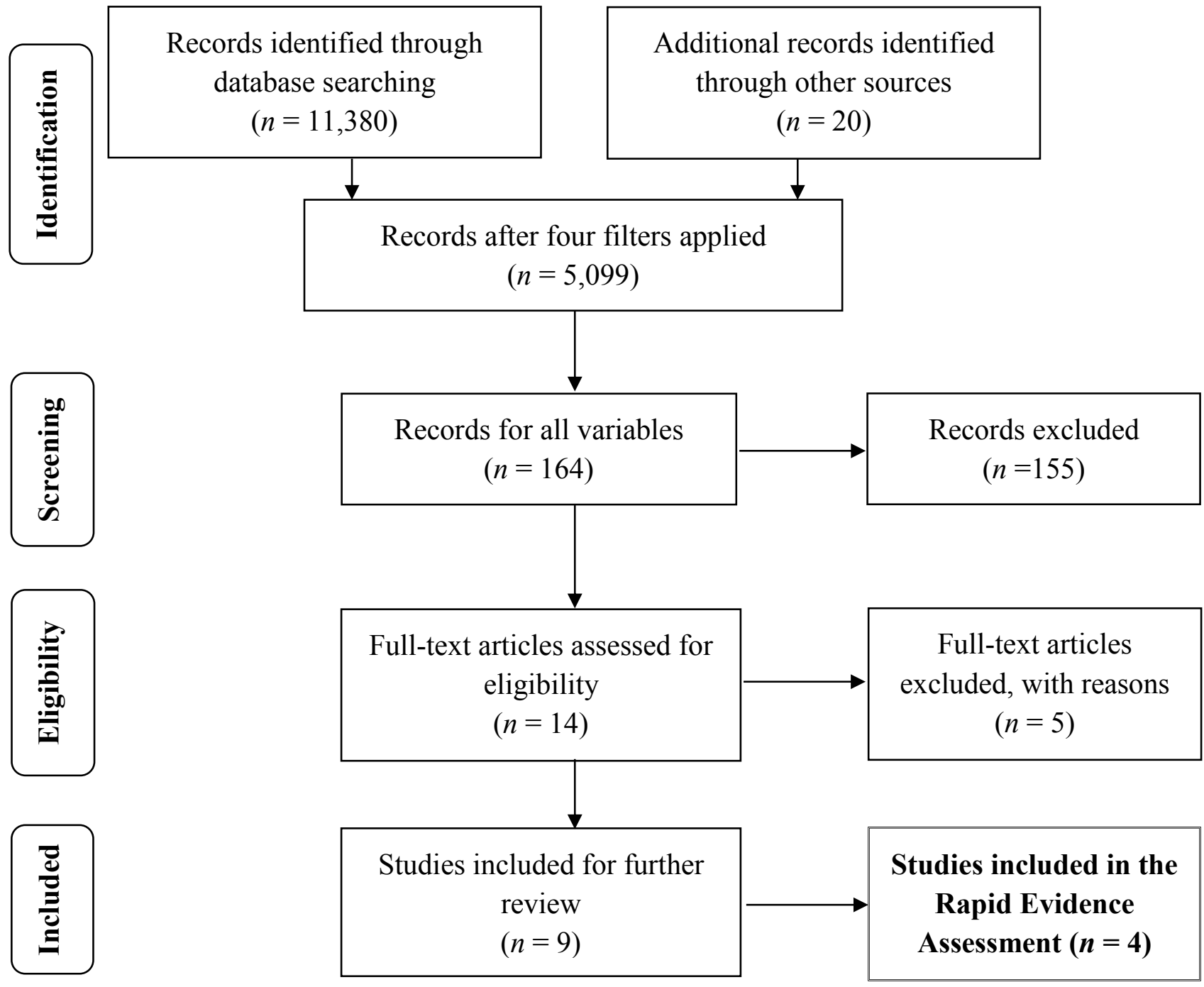

Figure 1: PRISMA Flow Diagram 
RAPE MYTHS, VICTIM BLAME AND JUST-WORLD BELIEFS

\subsubsection{Data Extraction}

Each article returned was assessed based on inclusion criteria (see Section 2.1.3). An initial review of the abstract was undertaken and subsequently, the full article, subject to the relevance of the abstracts.

\subsubsection{Quality Appraisal}

Using Gough's (2007) Weight of Evidence $\left(\mathrm{WoE}^{5}\right)$ framework, a quality appraisal was undertaken where the rigour of design, appropriateness of the study design (specific to the research question) and if the articles were relevant to the research question was assessed. Please see Appendix A for an explanation of the application of the WoE framework within the context of the current rapid evidence assessment.

\subsection{Findings}

An initial general search across databases using the keyword 'rape myth acceptance' yielded 11,380 results. Four key filters were then applied: full-text only, peer-reviewed articles, articles in the English language and articles published between 2009-2016, reducing the yield to 5,099 articles. A separate search was undertaken of the keyword 'rape myth acceptance' along with keywords representing each of the other variables. The results below are those returned subsequent to application of the exclusion criteria. Combining 'rape myth acceptance' and 'victim blaming' returned 67 articles, whereas 'rape myth acceptance', 'victim blaming' and 'Just World Belief' only generated two articles. A search based on 'rape myth acceptance' and 'victim gender' returned one article; 'rape myth acceptance' and 'perpetrator gender' yielded 6 articles. Using the keywords 'rape myth acceptance', 'victim blaming', and 'type of rape' produced 37 results. A table of keywords and returned resources can be found in Table 1. 
RAPE MYTHS, VICTIM BLAME AND JUST-WORLD BELIEFS

Table 1. Sources returned by keyword input

\begin{tabular}{lc}
\hline Keyword & Sources Returned \\
\hline 'Rape Myth Acceptance' & 11,380 \\
'Rape Myth Acceptance' \& 'Victim Blame' & 67 \\
'Rape Myth Acceptance', 'Victim Blame' \& 'Type of Rape' & 37 \\
'Rape Myth Acceptance' \& 'Perpetrator Gender' & 6 \\
'Rape Myth Acceptance', 'Victim Blame' \& 'Just World Belief' & 2 \\
'Rape Myth Acceptance' \& 'Victim Gender' & 1 \\
\hline
\end{tabular}

Following the application of exclusion / inclusion criteria, nine articles were retained for detailed evaluation. Each of the nine articles were examined based on the following criteria:

- Did the source answer or attempt to answer the research question?

- Was the source primarily focussed on RMA, VB attributions, whilst comparing gender of victim or gender of perpetrator and mentions type of rape?

- Published in or after 2009 (contemporary societal attitudes)?

If these three specific criteria were met, the sources were further scrutinised. From this secondary source review, a total of four articles were chosen for further review (see Table 2). These four articles were the only ones which satisfied all rigorous criteria. As previously mentioned, these four articles were examined using Gough's (2007) WoE framework (see Appendix A). Gough (2007) suggests that for a study to be rated highly regarding WoE D, it must be rated high for WoE A and B, and at least medium for WoE C. Presented below is a summary of sources returned (see Table 2), followed by a detailed discussion of each of the four identified sources. 
RAPE MYTHS, VICTIM BLAME AND JUST-WORLD BELIEFS

Table 2. Sources retained for detailed critical review

\begin{tabular}{|c|c|c|c|c|}
\hline Source & Design & Participants & Measures & Outcomes \\
\hline \multirow{4}{*}{$\begin{array}{l}\text { Grubb \& } \\
\text { Harrower } \\
(2009)\end{array}$} & \multirow[t]{4}{*}{$\begin{array}{l}\text { Between } \\
\text {-subject }\end{array}$} & \multirow{3}{*}{$\begin{array}{l}156 \\
\text { undergraduate } \\
\text { students }(101 \\
\text { females, } 55 \\
\text { males; } M_{\text {age }}= \\
24.32 \text { years })\end{array}$} & $\begin{array}{l}\mathrm{ARVS}^{6}, \mathrm{VBA}^{7} \text { and RMA } \\
\text { (full scales used) }\end{array}$ & $\begin{array}{l}\text { Males scored higher on ARVS and VBA than females but overall } \\
\text { scores were low }\end{array}$ \\
\hline & & & \multirow{2}{*}{$\begin{array}{l}\text { Judgement of } \\
\text { victim/perpetrator } \\
\text { responsibility }\end{array}$} & Males attributed more blame to victim than females \\
\hline & & & & $\begin{array}{l}\text { Overall, more VBA in seduction situation than date or stranger } \\
\text { rape }\end{array}$ \\
\hline & & $\begin{array}{l}\text { Opportunity } \\
\text { sampling used. }\end{array}$ & $\begin{array}{l}\text { Perceptions of similarity } \\
\text { to victim / perpetrator }\end{array}$ & No interaction between gender and type of rape \\
\hline \multirow{4}{*}{$\begin{array}{l}\text { Sleath \& } \\
\text { Bull }(2010)\end{array}$} & \multirow{4}{*}{$\begin{array}{l}\text { Between } \\
\text {-subject }\end{array}$} & \multirow{3}{*}{$\begin{array}{l}116 \text { participants } \\
(67 \text { females, } 49 \\
\text { males; } M_{\text {age }}= \\
19.23)\end{array}$} & \multirow{4}{*}{$\begin{array}{l}\text { Victim/ Perpetrator Blame } \\
\text { Scale } \\
\text { MRMS }^{8}, \text { JWB }^{\text {and SRES }}{ }^{9} \\
\text { (SRES short form was } \\
\text { used) }\end{array}$} & RMA of males had a strong relationship with male VB \\
\hline & & & & Acceptance of stereotypical attitudes of male rape resulted in \\
\hline & & & & greater likelihood of male rape VB \\
\hline & & $\begin{array}{l}\text { Opportunity } \\
\text { sampling was } \\
\text { used. }\end{array}$ & & \\
\hline \multirow{5}{*}{$\begin{array}{l}\text { Hayes, } \\
\text { Lorenz, \& } \\
\text { Bell (2013) }\end{array}$} & \multirow{5}{*}{$\begin{array}{l}\text { Within- } \\
\text { subject }\end{array}$} & \multirow{3}{*}{$\begin{array}{l}351 \text { Psychology } \\
\text { undergraduates. } \\
\text { (241 females, } \\
110 \text { males). }\end{array}$} & \multirow{5}{*}{$\begin{array}{l}\text { JWB and RMA (short } \\
\text { form) }\end{array}$} & Males scored higher on RMA than females \\
\hline & & & & JWB-self negatively associated with RMA and lower VB \\
\hline & & & & JWB-other associated with higher VB \\
\hline & & \multirow{2}{*}{$\begin{array}{l}\text { No age was } \\
\text { stated by } \\
\text { researchers }\end{array}$} & & Males marginally higher in JWB-self than females \\
\hline & & & & No mediation between gender and VB \\
\hline $\begin{array}{l}\text { Ayala, } \\
\text { Kotary \& } \\
\text { Hetz }(2015)\end{array}$ & $\begin{array}{l}\text { Between } \\
\text {-subject }\end{array}$ & $\begin{array}{l}200 \text { female } \\
\text { Psychology } \\
\text { undergraduates }\end{array}$ & $\begin{array}{l}\text { Blame attributions } \\
\text { adapted as appropriate for } \\
\text { the study, perpetrator }\end{array}$ & $\begin{array}{l}\text { RMA, victim/perpetrator gender influence blame attributions for } \\
\text { both victims and perpetrators }\end{array}$ \\
\hline
\end{tabular}


RAPE MYTHS, VICTIM BLAME AND JUST-WORLD BELIEFS

\begin{tabular}{|c|c|c|}
\hline$\left(M_{\mathrm{age}}=21.38\right)$ & responsibility, victim & Lower RMA associated with lower VB (female perpetrator) \\
\hline Target sample & $\begin{array}{l}\text { sympathy, perceived } \\
\text { consequences of offence }\end{array}$ & Male perpetrator blame was highest \\
\hline $\begin{array}{l}\text { was female } \\
\text { college students } \\
\text { exposed to } \\
\text { feminist } \\
\text { discourse and } \\
\text { beliefs. }\end{array}$ & IRMA $^{10}$ (short form) & $\begin{array}{l}\text { Type of relationship was not significantly associated with } \\
\text { victim/perpetrator blame. }\end{array}$ \\
\hline
\end{tabular}


RAPE MYTHS, VICTIM BLAME AND JUST-WORLD BELIEFS

Three of the four articles retained used a vignette design. Hayes et al. (2013) was the only study who did not use a vignette in their design. The remaining three articles all used vignettes specifically created for their research. Grubb and Harrower (2009) did not mention the words 'victim', 'complainant' or 'rape'; this was to ascertain that participants determined their own conclusions about the incident in the vignette and not use pre-conceptions of the words rape, victim or complainant. Their vignette was approximately 350 words in length. This was similar to Sleath and Bull (2010) and Ayala et al. (2015), in which the word victim or rape was not used. Sleath and Bull's vignette was approximately 100 words in length and the length of Ayala's vignette is unknown.

\subsubsection{Grubb and Harrower (2009)}

Understanding attribution of blame in cases of rape: An analysis of participant gender, type of rape and perceived similarity to the victim

Grubb and Harrower (2009) investigated factors which influence attitudes towards rape and rape victims. They investigated participant gender, type of rape (stranger, date and acquaintance rape) and participants' perceived similarity to victim and perpetrator. They used a vignette and survey method to measure 156 UK undergraduate participants' attitudes towards rape victims, their VB attributions, judgement of victim and perpetrator responsibility and RMA score. Participants were randomly assigned to one of three vignette conditions describing one of the rape situations: stranger rape, date rape or acquaintance rape. Male participants attributed more blame to the victim compared with female participants, measured using the Attitudes towards Rape Victims Scale (ARVS ${ }^{6}$; Ward, 1988), however they noted that less favourable attitudes towards victims was relatively uncommon in both male and female participants. A main effect for type of rape and similarity to the perpetrator was found; participants reported feeling more similar to the perpetrator in the seduction rape condition than in stranger and date rape scenarios. Seduction rape was operationalised as a 
RAPE MYTHS, VICTIM BLAME AND JUST-WORLD BELIEFS

male seducing a female in a bar, before leaving / going home together; therefore they were neither on a date nor in a relationship (Grubb \& Harrower, 2009)

A significant main effect of participant gender was found, whereby males blamed the victim more than the female participants. Furthermore, participants attributed more blame to victims of the seduction rape condition than the date or stranger rape conditions. Overall, male participants scored higher on the ARVS and VB scales than females, therefore showing a higher level of RMA and VB attitudes, regardless of the type of rape the vignette depicted. Likewise, participants attributed more VB to the seduction rape condition, followed by date rape and finally stranger rape conditions.

Grubb and Harrower (2009) reported that males scored higher than females in the ARVS, suggesting that male participants may have made harsher judgements than female participants. However, both scores of male and female participants were relatively low.

WoE D: Based on recognised criteria (Appendix A), the study by Grubb and Harrower (2009) appeared to be of medium quality overall. In relation to the general aims of this REA, the study had an appropriate methodology, the methods were made explicit, and thus interpretation of results followed clearly. Although sample size and population were suitable, the results may not be generalisable to the wider population.

\subsubsection{Sleath and Bull (2010)}

Male Rape Victim and Perpetrator Blaming

Sleath and Bull (2010) investigated attitudes towards male rape victims with regards to male RMA. The authors discussed egalitarian sex-role beliefs surrounding gender which portrays the participants' victim and perpetrator blaming attributions. Manipulation of type of rape (stranger vs. acquaintance) and the severity of the rape (low vs. high) allowed the authors to examine the 116 undergraduate participants' attitudes and JWBs. They used a vignette and survey method in which was to be completed online by means of a between- 
RAPE MYTHS, VICTIM BLAME AND JUST-WORLD BELIEFS

participant design. Overall, Sleath and Bull (2010) found no main differences of JWB between males and females. The level of RMA ranged from $2-92 \%$ for each statement both male and female participants rated. However, it was found that males accepted myths more than female participants and that males scored higher in egalitarian sex-role beliefs. The authors found that higher RMA was predicted by high egalitarian beliefs and pronounced JWBs. Furthermore, it was also reported that RMA and higher egalitarian beliefs were predictors of perpetrator blaming. Higher levels of RMA were predicted by high levels of egalitarian beliefs. Thus, as males were more accepting of male-victim rape-myths, they were also more egalitarian in their sex-role beliefs (Sleath \& Bull, 2010). Moreover, the victim of acquaintance rape was blamed at a higher level than the victim of stranger rape by both males and females. One limitation of the study conducted by Sleath and Bull (2010) is that the rape scenarios depicted only male victims, and therefore did not address the variable of victim gender.

WoE D: Medium: In general, the study had clarity and the methodology clearly followed the previous literature discussed. The methodology appeared appropriate; however there are concerns of the sample size and population, as results may not be generalisable. Nevertheless, the conclusions provided clear and relevant answers to the research aim.

\subsubsection{Hayes, Lorenz and Bell (2013)}

Victim Blaming Others: Rape Myth Acceptance and the Just World Belief

Hayes et al. (2013) examined JWBs and their relationship with VB attributions. These two concepts both differ between genders; therefore, gender was also a variable in the study when associated with a sexual assault. The present study involved 351 students resident in the USA, and a survey method was used alongside open- and closed-ended questions. Overall, the authors found that males were more likely to accept rape myths than females. JWBs of the self were negatively associated with RMA; thus higher JWBs were associated with lower 
RAPE MYTHS, VICTIM BLAME AND JUST-WORLD BELIEFS

RMA and vice versa. Furthermore, JWBs of others were positively associated with RMA; as JWBs of others increased, RMA also increased. Males were marginally more likely than females to believe in a Just World for themselves; however there was no effect of gender on JWBs of others. Hayes et al., (2013) reported moderately low levels of RMA for both male and female participants.

WoE D: Overall High: The methodological techniques employed were sound and robust, however regarding the limitations mentioned previously, the conclusions provided could be clearer. Nevertheless, the research question clearly followed the literature presented, the main aim of the research question was addressed, and the sample size was large.

\subsubsection{Ayala, Kotary and Hetz (2015)}

Blame Attributions of Victims and Perpetrators: Effects of Victim Gender, Perpetrator Gender and Relationship

Ayala et al. (2015) studied the roles of victim and perpetrator gender, type of rape and RMA of female participants. This study investigated 221 American female participants (who may hold feminist beliefs and values). Ayala et al. report that participants in the sample included a women's college in which the institution 'promotes feminist values through its core curriculum'. The curriculum includes feminist theories, gender differences and social justice for women.

The authors adopted a $1($ RMA $) \times 2($ victim gender $) \times 2($ perpetrator gender $) \times 2($ type of relationship) design in which female participants were randomly assigned to one of eight conditions and were asked to read a vignette describing a sexual assault, then complete two scales. Ayala et al. (2015) manipulated the gender of the perpetrator to measure the change in RMA between male and female perpetrators. The scales measured the participants' attitudes and perceptions concerning the victim, the perpetrator, the type of rape (stranger or acquaintance) and RMA. The results of this study revealed no overall interaction between the 
RAPE MYTHS, VICTIM BLAME AND JUST-WORLD BELIEFS

four independent variables (RMA, victim gender, perpetrator gender, relationship type) and the two dependent variables (VB, perpetrator blame). Nevertheless, a significant relationship between RMA and victim gender was found regarding victim and perpetrator blame. Lower levels of RMA were associated with lower levels of VB for both female and male victims. However, a negative association was found between RMA and perpetrator blame, particularly when the scenario depicted a male victim. Another significant association was found between RMA and perpetrator blame - RMA was low for female perpetrators but significantly higher for male perpetrators. However, there was no association between RMA and type of rape depicted in the vignettes and similarly there was no significant relationship between victim and perpetrator blame and type of rape (stranger- vs. acquaintance-rape). Across conditions, levels of RMA were relatively low (Ayala et al., 2015).

WoE D: Medium: This study was methodologically sound, and the rationale and methods were explicit. An adequately large sample size and vignette/survey method was appropriate for this type of research. However, the purpose of involving female-only participants was not made explicit and therefore is a limitation of the study.

\subsection{Discussion}

\subsubsection{Summary of reviewed articles}

The overall findings from the four sources reviewed are that RMA is more prevalent in male respondents than females, and that RMA is correlated with VB attributions (Sleath \& Bull, 2010). Moreover, JWBs were also associated with RMA and VB attributions (Hayes et al., 2013). Another key finding was that more blame was attributed to victims/complainants in seduction rape scenarios than date or stranger rape (Grubb \& Harrower, 2009); however in other studies, no significant relationship between type of rape (stranger or acquaintance) and victim/perpetrator blame was reported (Ayala et al., 2015). The studies investigated ample- 
RAPE MYTHS, VICTIM BLAME AND JUST-WORLD BELIEFS

sized groups in the UK and USA, and overall have built upon previous literature that RMA is most commonly found in males, where complainants are often blamed regardless of the situation it occurred in. Three of the sources employed vignettes, which allowed participants to make informed judgements regarding specific scenarios.

Accordingly, it has been claimed that participant gender is a significant factor regarding RSAs and VB. Grubb and Harrower (2009) found that males scored higher on both scales, in line with much previous literature regarding gender (Hayes et al., 2013). The finding that RSAs are more prevalent in males has been studied using a variety of methodological measures and reveals that men are more likely to accept myths of this nature. Sleath and Bull's (2010) investigation into male RMA illustrated that even when the victim is male, male respondents were still more accepting of rape myths. Contradictory findings are confounded by inconsistencies between studies.

The current REA revealed that there is a lack of research regarding homosexual rape, in particular of female-perpetrator to female-victim rape. Of course, one reason could be the definition of rape, which changed in the UK in the early noughties. Forceful penetration/entry without consent is now regarded as rape regardless of gender of perpetrator; therefore, although penetration with a penis cannot occur between two females, changes in UK law mean that, for example, digitally penetrating an individual without consent is now considered rape.

The main observations from this rapid evidence assessment are that a number studies have investigated the difference between male and female student responses to female and male rape; nevertheless, very few directly compare gender differences. Similarly, investigating the differences of victim and perpetrator gender and type of rape has been neglected. The RSAs of laypeople is influenced by complainant gender, perpetrator gender and type of rape (stranger vs. marital), however a single study to directly investigate these 
RAPE MYTHS, VICTIM BLAME AND JUST-WORLD BELIEFS

three variables was not identifiable. It is noteworthy that RMA is often viewed as a stable construct which is resilient to short-term changes induced by experimental manipulation. Future research should consider measures of RMA as a covariate or moderating / mediating variable in statistical analyses. However, measures of RMA prior to and after an educational intervention could provide vital insight into the efficacy of any such pro-social interventions.

The findings of the current rapid evidence assessment are clear in that participants are mostly undergraduates, and it may not be possible to conclude if there has been a casual inference within a research paper if most respondents are students. Conducting a study using only students poses the question: can the results be generalised within a heterogeneous population? Thus, the findings of any student-populated study may not be externally valid or have generalisability (Druckman \& Kam, 2009). However, Druckman and Kam (2009) state that the generalisability of a student population is dependent on whether prior research has built a relationship between the population and the area of research. Strömwall and colleagues (2012) also commented on the use of undergraduate students as the main respondents and suggested that this can convey a sample bias. Furthermore, generalisability from US undergraduate participant samples is potentially further compromised as a result of sexual violence prevention programmes becoming mandatory since the early part of the $21^{\text {st }}$ century. It is important to therefore conduct future research utilising a sample of participants that is representative of a broader population.

\subsubsection{Evaluation of the rapid evidence assessment approach}

The current rapid evidence assessment provides a quality overview of studies in the area searched; nevertheless, it is not a full systematic review and does not consider 'grey literature'. McMurran (2012) acknowledges that using a rapid evidence assessment may result in important articles being excluded from the search. Limiting the search may have resulted in some literature, which is very important regarding RMA and VB but not 
RAPE MYTHS, VICTIM BLAME AND JUST-WORLD BELIEFS

completely meeting the inclusion criteria, to be disregarded. However, an advantage of the current rapid evidence assessment showed the existing evidence-base has consistently used the same or similar methodological measures, which may prove the reliability and conclusiveness of the studies discussed. Hence, generalisation of findings and conclusions across these four articles is legitimate.

\subsubsection{Implications}

Overall, these studies provided an overview regarding RMA, JWB and VB attributions. There is potential for future research to qualitatively understand the reason behind the general population to hold RSAs and demonstrate RMA. Foubert and Marriot (1997) found that males who attended a programme focussing on sexual assault resulted in lower RMA compared to pre-programme levels. It has also been found that simply completing the Burt RMA Scale (Burt, 1980) raised awareness of rape-myths in both males and females; therefore, it could be suggested that raising awareness of rape-myths and their effects may be effective in tackling such attributions among the lay public. Foubert and Marriot (1997) suggest that administering the scale allows the layperson to understand the negative effects RMA can have on complainants.

Grube, Mayton and Ball-Rokeach (1994) state that a lasting change of attitudes and behaviours is very difficult to achieve, but state that a male's attitudes towards complainants were successfully adapted when males felt they were being asked as potential altruistic interventionists rather than as implied potential perpetrators. Moreover, Fox and Cook (2011) state that educating the layperson may decrease the likelihood of secondary victimisation, such as condemnation, disbelief the event occurred or inaction from officials (Crome $\&$ McCabe, 2001; Doerner \& Lab, 2008; Karmen, 2007).

Sleath and Bull (2010) agree and add that these attitudes could also be prevented in police officers too. Therefore, future research could also involve investigating RSAs and VB 
RAPE MYTHS, VICTIM BLAME AND JUST-WORLD BELIEFS

attributions in police officers and how this impacts the judicial process. Moreover, future research of this nature could illustrate the psychological reasons behind RMA and why these attitudes are exacerbated by specific factors.

\subsubsection{Conclusions}

From the findings presented in the current rapid evidence assessment, it is evident that there is scope for further investigation into RSAs, complainant/perpetrator gender and type of rape. The articles reported used similar methodological designs, in which vignettes and survey methods were typical, highlighting the ability to compare these articles and conclude on the findings presented. A concern is that all four incorporated sources utilised a student sample. There are concerns about the representativeness of such samples. Further, if we consider the extension of these results to criminal justice and practices, it is highly unlikely that a jury would be composed entirely of university students. Future research should look at a more diverse sample of participants, across demographics such as sex, gender identity, sexual identity, socio-economic status, and other key demographic variables important when considering impression formation.

One of the most important issues to be addressed is marital rape, and more specifically homosexual marital rape. Are male participants more likely to blame a male complainant in a marital rape situation? Are participants more likely to blame the complainant, when both they and alleged perpetrator are female? Despite the limitations discussed in the current rapid evidence assessment, important issues have been identified for further empirical research. 
RAPE MYTHS, VICTIM BLAME AND JUST-WORLD BELIEFS

\subsection{References}

Ayala, E. E., Kotary, B., \& Hetz, M., (2015). Blame Attributions of Victims and Perpetrators: Effects of Victim Gender, Perpetrator Gender and Relationship. Journal of Interpersonal Violence, 1-23. DOI: 10.1177/0886260515599160

Berry, G., Briggs, P., Erol, R., \& van Staden, L. (2011). The effectiveness of partnership working in a crime and disorder context: A rapid evidence assessment. London: Home Office Research Report.

Burt, M. (1980). Cultural myths and supports for rape. Journal of Personality and Social Psychology, 38, 217-23

Crome S. A., \& McCabe, M. P. (2001). Adult rape scripting within a victimological perspective. Aggression and Violent Behavior, 6, 395-413.

Doerner,W. G., \& Lab, S. P. (2008). Victimology (5th ed.). Cincinnati, OH: LexisNexis/Anderson Publishing Company.

Dalbert, C. (2009). Belief in a just world. In M. R. Leary \& R. H. Hoyle (Eds.), Handbook of individual differences in social behavior (pp. 288-297). New York: Guilford.

Davies, P. (2003). The Magenta Book: guidance notes for policy evaluation and analysis. London: Government Social Research Unit.

Davies, M., Pollard, P., \& Archer, J. (2006). Effects of Perpetrator Gender and Victim Sexuality on Blame toward Male Victims of Sexual Assault. The Journal of Social Psychology, 146(3), 275-291. DOI:10.3200/SOCP.146.3

Davies, M., Walker, J., Archer, J., \& Pollard, P. (2010). A comparative study of long-term psychological functioning in male survivors of stranger and acquaintance rape. 
RAPE MYTHS, VICTIM BLAME AND JUST-WORLD BELIEFS

Journal of Aggression, Conflict and Peace Research, 2(4), 25-33. DOI http://dx.doi.org/10.5042/jacpr.2010.0534

Druckman, J. N., \& Kam, C. D. (2009). Students as Experimental Participants: A Defense of “Narrow Data Base.” In J. N. Druckman, D. P. Green, J. H. Kuklinski, \& A. Lupia (Eds.). Handbook of Experimental Political Science (pp. 41-57) .New York: Cambridge University Press.

Duff, S., \& Tostevin, A. (2015). Effects of gender, rape myth acceptance, and perpetrator occupation on perceptions of rape, Journal of Criminal Psychology, 5(4), 249 - 261. DOI: http://dx.doi.org/10.1108/JCP-12-2014-0019

Ferro, C., Cermele, J., \& Saltzman, A., (2008). Current Perceptions of Marital Rape: Some Good and Not-So-Good News. Journal of Interpersonal Violence, 23(6), 764-779. DOI: $10.1177 / 0886260507313947$

Flately, J. (2016). Statistical Bulletin: Crime in England and Wales: Year ending December 2015. Office for National Statistics. Available online:

http://www.ons.gov.uk/peoplepopulationandcommunity/crimeandjustice/bulletins/cr imeinenglandandwales/yearendingdecember2015

Flately, J. (2017). Statistical Bulletin: Crime in England and Wales: Year ending December 2016. Office for National Statistics. Available online: https://www.ons.gov.uk/peoplepopulationandcommunity/crimeandjustice/bulletins/cri meinenglandandwales/yearendingdec2016

Foubert, J. D., \& Marriott, K. A. (1997). Effects of a sexual assault peer education program on men's belief in rape myths. Sex Roles, 36(3-4), 259-268. 
RAPE MYTHS, VICTIM BLAME AND JUST-WORLD BELIEFS

Fox, K. A., \& Cook, C. L. (2011). Is knowledge power? The effects of a victimology course on victim blaming. Journal of interpersonal violence, 26(17), 3407-3427.

Frese, B., Moya, M., \& Megias, J.L. (2004). Social perception of rape: how rape myth acceptance modulates the influence of situational factors, Journal of Interpersonal Violence, 19(2), 143-61. DOI: 10.1177/0886260503260245

Gough, G. (2007). Weight of Evidence: a framework for the appraisal of the quality and relevance of evidence. Research Papers in Education, 22(2), 213-228. DOI:10.1080/02671520701296189

Grubb, A. R. \& Harrower, J. (2009). Understanding attribution of blame in cases of rape: An analysis of participant gender, type of rape and perceived similarity to the victim. Journal of Sexual Aggression, 15(1), 63-81. DOI: 10.1080/13552600802641649

Grubb, A. R. \& Turner, E. (2012). Attribution of blame in rape cases: a review of the impact of rape myth acceptance, gender role conformity and substance use on victim blaming, Aggression and Violent Behaviour, 17(5), 443-52.

Grube, J. W., Mayton, D. M., \& Ball-Rokeach, S. J. (1994). Inducing change in values, attitudes, and behaviors: Belief system theory and the method of value selfconfrontation. Journal of social issues, 50(4), 153-173.

Gurnham, D. (2016). Victim-blame as a symptom of rape myth acceptance? Another look at how young people in England understand sexual consent. Legal Studies, 32(2), 258278. DOI: $10.1111 /$ lest.12107

Hayes, R. M., Lorenz, K., \& Bell, K. A. (2013). Victim Blaming Others: Rape Myth Acceptance and the Just World Belief. Feminist Criminology, 8(3), 202-220. DOI: $10.1177 / 1557085113484788$ 
RAPE MYTHS, VICTIM BLAME AND JUST-WORLD BELIEFS

Karmen, A. (2007). Crime victims: An introduction to victimology (6th ed.). Belmont, CA: Thomson Wadsworth.

Lerner, M., \& Simmons, C. H. (1966). Observer's Reaction to the 'Innocent Victim':

Compassion or Rejection?. Journal of Personality and Social Psychology. 4(2), 203210. doi:10.1037/h0023562

Lodewijkx, H. F., Wildschut, T., Nijstad, B. A., Savenije, W., \& Smit, M. (2001). In a violent world a just world makes sense: The case of senseless violence in the Netherlands. Social Justice Research, 14(1), 79-94.

Mahoney, P., \& Williams, L. (1998). Sexual assault in marriage: prevalence, consequences and treatment of wife rape, in J. Jasinski, and L. Williams, (Eds), Partner Violence: A Comprehensive Review of 20 years of Research, Sage, Thousand Oaks, CA, pp. $113-63$.

McMurran, M. (2012). Individual-level interventions for alcohol-related violence: A rapid evidence assessment. Criminal Behaviour and Mental Health, 22, 14-28. DOI: $10.1002 / \mathrm{cbm} .821$

Ministry of Justice (2013). Official Statistics: An Overview of Sexual Offending in England and Wales. Statistical Bulletin; Office for National Statistics. Available online: https://www.gov.uk/government/statistics/an-overview-of-sexual-offending-inengland-and-wales

Office for National Statistics (2016). Crime in England and Wales: Year ending December 2015. Statistical Bulletin. 
RAPE MYTHS, VICTIM BLAME AND JUST-WORLD BELIEFS

Osman, S., (2014). Participant sexual victimisation by an acquaintance and gender predicting empathy with an acquaintance or stranger rape victim. Journal of Social and Clinical Psychology, 33(8), 732-742.

Pawson, R., Boaz, A., Grayson, L., Long, A., \& Barnes, C. (2006) Types and quality of knowledge in social care, Knowledge Review 3, London: SCIE.

Payne, D. L., Lonsway, K. A., \& Fitzgerald, L. F. (1999). Rape myth acceptance: Exploration of its structure and its measurement using the Illinois Rape Myth Acceptance Scale. Journal of Research in Personality, 33, 27-68. doi:10.1006/jrpe.1998.2238

Rye, B. J., Greartrix, S. A., \& Enright, C. S. (2006). The Case of the Guilty Victim: The Effects of Gender of Victim and Gender of Perpetrator on Attributions of Blame and Responsibility. Sex Roles, 54, 639-649. DOI 10.1007/s11199-006-9034-y

Scottish Government Statistics (2015). Recorded Crime in Scotland, 2014-2015. Retrieved from http://www.gov.scot.uk/publications/recent [Accessed 05 June 2016].

Sexual Offences Act (2003). Retrieved from http://www.legislation.gov.uk/ukpga/2003/42/pdfs/ukpga_20030042_en.pdf (date accessed 07/06/2017)

Sleath, E., \& Bull, R. (2010). Male Rape Victim and Perpetrator Blaming, Journal of Interpersonal Violence, 26(6), 969-988. DOI: 10.1177/0886260509340534

Sleath, E., \& Woodhams, J. (2014). Expectations about victim and offender behaviour during stranger rape. Psychology, Crime \& Law, 20(8), 798-820. DOI: 10.1080/1068316X.2013.876500 
RAPE MYTHS, VICTIM BLAME AND JUST-WORLD BELIEFS

Strömwall, L.A., Alfredsson, H., \& Landström, S. (2012) Blame attributions and rape: Effects of belief in a just world and relationship level. Legal and Criminological Psychology, 18, 254-261. DOI:10.1111/j.2044-8333.2012.02044.x

The Sexual Offences (Scotland) Act 2009. Available at http://www.legislation.gov.uk/asp/2009/9 [Accessed 03 June 2016].

The UK Government (2010). Guidance on the Sexual Offences (Scotland) Act 2009 retrieved from: https://www.gov.uk [Accessed 16 June 2016].

The UK Government statistics (2015). Recorded Crime, 2014-15. Retrieved from http://www.gov.uk.government/statistics [Accessed 15 June 2016].

Ward, C. (1988). The Attitudes toward rape victims scale: Construction, Validation and Cross-Cultural Applicability. Psychology of Women Quarterly, 12, 127-146.

Whatley, M. A. (2005). The effect of participant sex, victim dress, and traditional attitudes on causal judgments for marital rape victims. Journal of Family Violence, 20(3), 191200. DOI: $10.1007 / \mathrm{s} 10896-005-3655-8$ 
RAPE MYTHS, VICTIM BLAME AND JUST-WORLD BELIEFS

\section{Appendix A}

Gough's (2007) Weight of Evidence Framework

Weight of Evidence A: A generic (thus non review-specific) judgement about the coherence and integrity of the evidence in its own terms. That may be the generally accepted criteria for evaluating the quality of this type of evidence by those who generally use and produce it.

Weight of Evidence B: A review-specific judgement about the appropriateness of that form of evidence for answering the review question, i.e., the fitness for purpose of that form of evidence. For example, the relevance of certain research designs such as experimental studies when addressing questions about process.

Weight of Evidence $C$ : A review-specific judgement about the relevance of the focus of the evidence for the review question. For example, a research study may not have the type of sample, the type of evidence gathering or analyses central to the review question. Further, the study may not have been undertaken in an appropriate context from which results can be generalized to answer the specific research question. There may also be issues of propriety of how the research was undertaken, such as ethics considerations, that could impact on its inclusion and interpretation in a review (Pawson, Boaz, Grayson, Long, \& Barnes, 2006). These three judgements can then be combined to form an overall assessment Weight of Evidence $D$ of the extent that a study contributes evidence to answering a specific research question. 